\title{
Review of: "Managing Groundwater Resources Using A National Reference Database The French ADES Concept"
}

\author{
Costantino Masciopinto ${ }^{1}$ \\ 1 Italian National Research Council
}

Potential competing interests: The author(s) declared that no potential competing interests exist.

In this paper, the authors describe the great potentialities of the national French database named ADES (Accès aux Données sur les Eaux Souterraines or access to the groundwater data), to be used by a user in the world for the groundwater management in France. Following authors "ADES database makes available on a public site millions of standardized data on groundwater quality and water levels in France ..... data are supplemented by metadata providing an unequivocal understanding .... free access to the data and their standardization allows people other than producers and managers to consult and download them."

Unfortunately, I have made several attempts to consult ADES and obtain some specific information but web links for the download yield unavailable information or errors. There is the possibility to download "zip" files of many single well or spring containing tables in "TXT" or "CSV" format (Fig. 1)

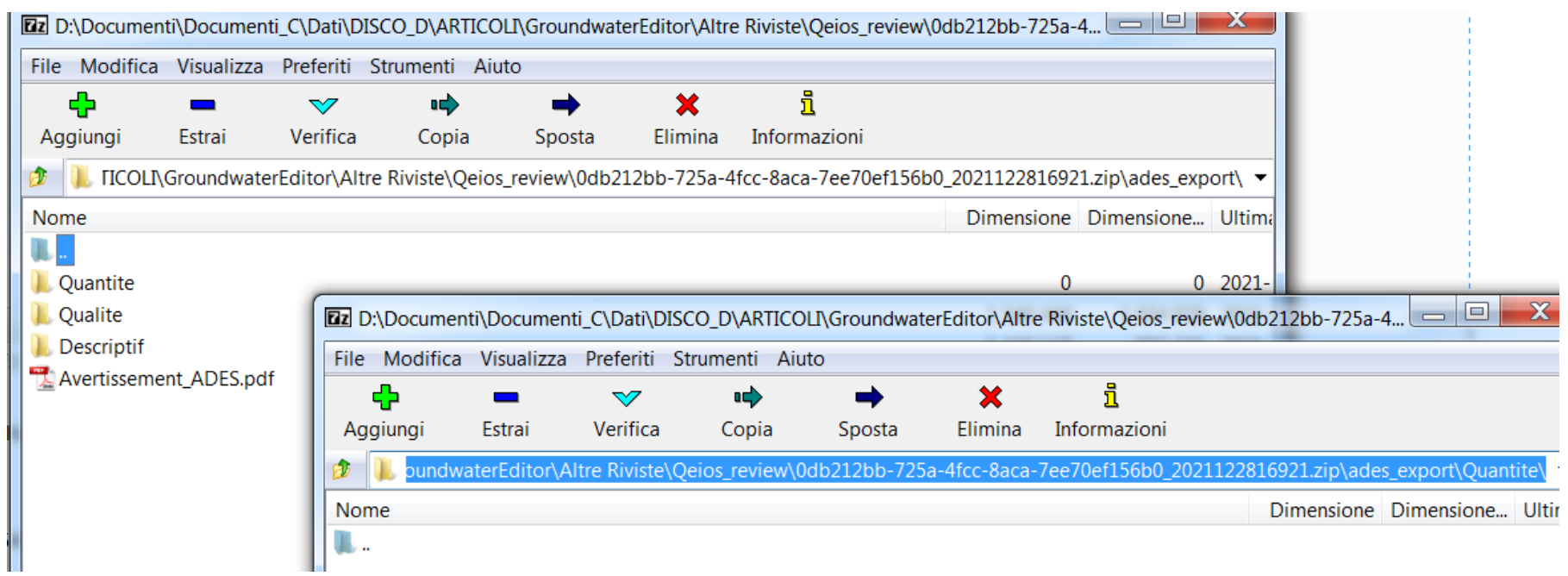




\begin{tabular}{|llll|}
\hline 문 80936602-cdb3-46fc-87b8-11639b36f34... & $11 / 01 / 2022$ 18:20 & zip Archive & 2,255 KB \\
\hline 미 0db212bb-725a-4fcc-8aca-7ee70ef156b... & $28 / 12 / 2021$ 16:10 & zip Archive & 2,205 KB \\
\hline
\end{tabular}

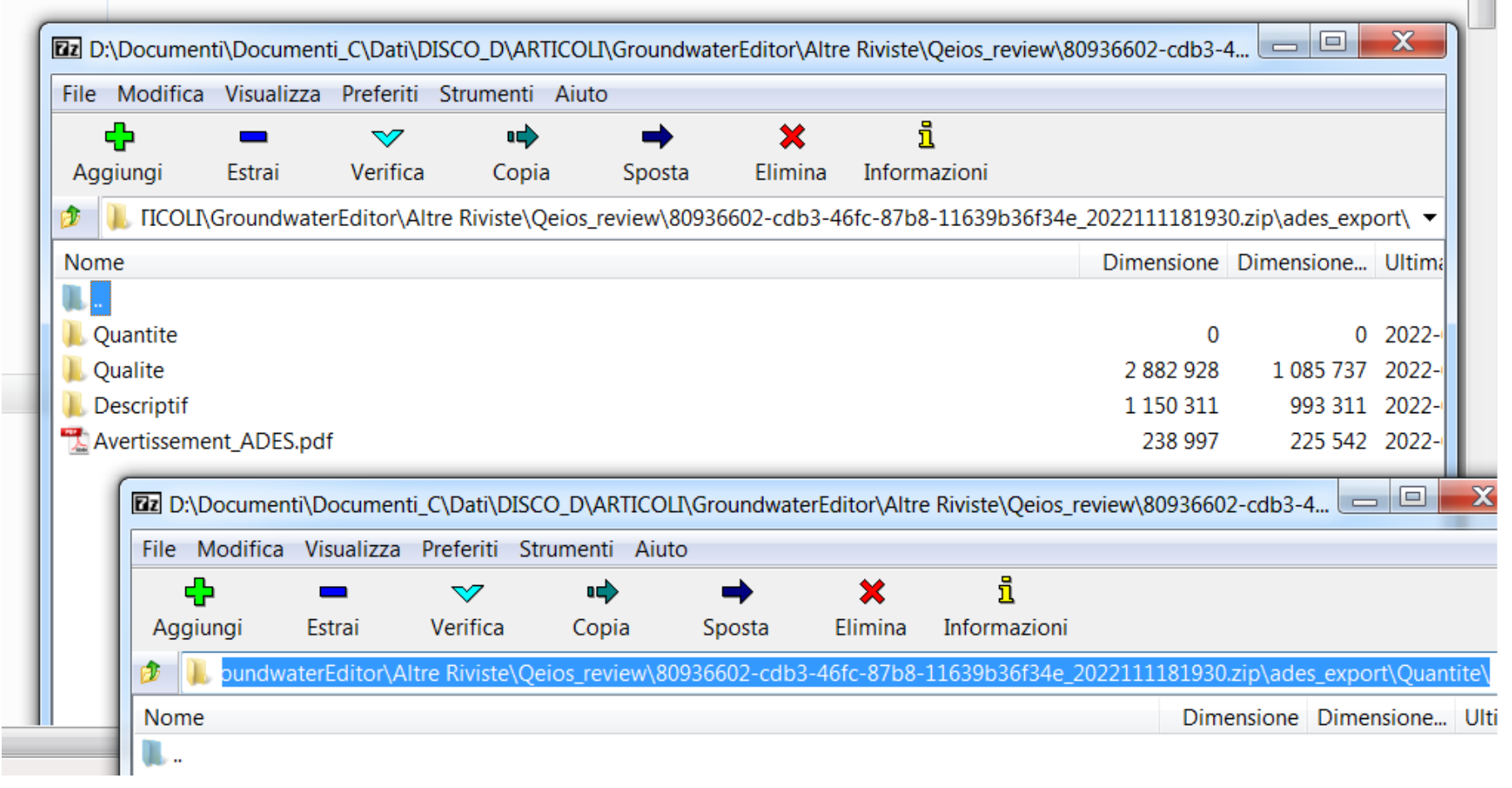

Fig. 1. ADES archives of the groundwater quality (pollutants or electrolytes) and quantity (i.e., water depth and groundwater piezometric head)

Although the ADES interface can visualize graphs and geological maps of collected data, the downloaded tables are not easy to read owing to many text descriptions and very sparse (sometimes two or three data per file) data required for modeling the groundwater management. Authors have written in the paper that: “... The ADES database makes available on a public site millions of standardized data” on groundwater quality and water levels in France... “, but word strings are repeated at every line on the table (Fig. 2) instead of the international standard units.

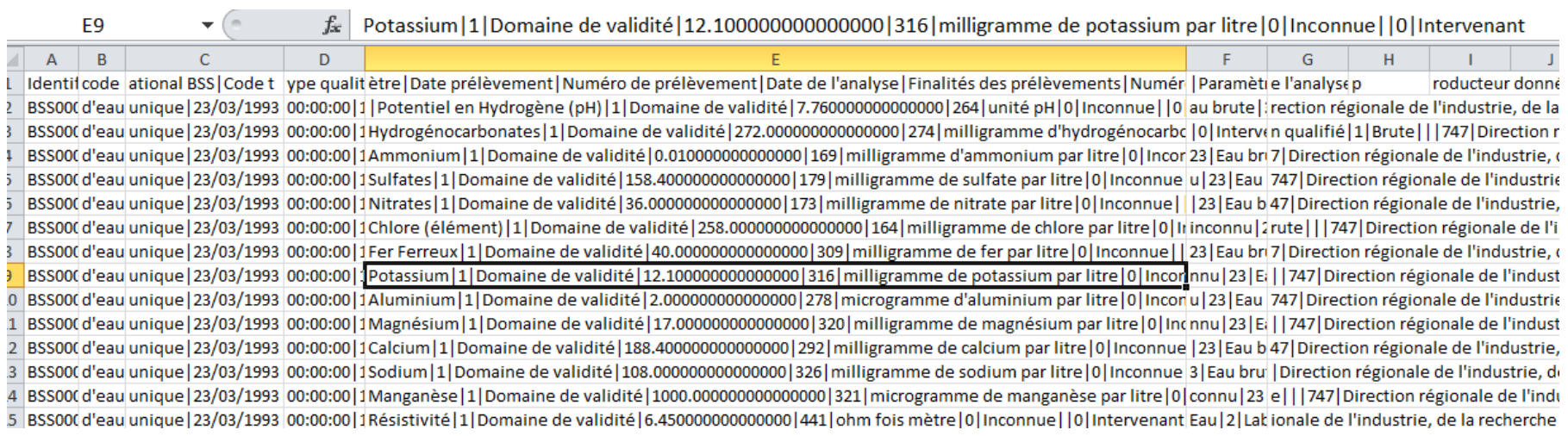

Fig. 2. ADES table of quality data (electrolyte concentrations) collected at a specific well

Specifically, I was unable to find on the ADES website data such as the pumping well flowrate and corresponding water table drawdown. Also, aquifer transmissivity or/and hydraulic conductivity are 
frequently (or always) missing on tables (fig. 3) visualized by ADES.

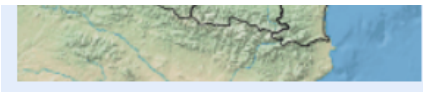

Nature

Forage

État du point d'eau

Non renseignée

Fonction du point d'eau

Non renseignée

Usage de l'eau

Non renseignée

Bassin

Artois-Picardie

Département

Pas-De-Calais (62)

Commune actuelle

Chocques (62224)

Lieu-dit

Hors Concession 62 - Ancienne Cokerie De Chocques

Coordonnées X, Y (Lambert 93)

$X: 669775 / Y: 7048937$ (m NGF)

\section{Altitude}

$27 \mathrm{~m}$

Carte géologique au 1/50 000 Bethune ( $n^{\circ}$ 0019)

Renseignement complémentaires

- Fiche InfoTerre
Aucune donnée disponible dans le tableau

L'historique des associations des versions antérieures du référentiel est disponible dans le dossier descriptif de l'export du point d'eau (format csv)

- Rattachement du point d'eau au référentiel des masses d'eau souterraine

\begin{tabular}{|c|c|c|c|c|c|}
\hline $\begin{array}{l}\text { Code masse } \\
\text { d'eau }\end{array}$ & $\begin{array}{l}\text { Version du } \\
\text { référentiel }\end{array}$ & $\begin{array}{l}\text { Nom de la } \\
\text { masse d'eau }\end{array}$ & $\begin{array}{l}\text { Date de } \\
\text { début }\end{array}$ & $\begin{array}{l}\text { Qualité de l'association point } \\
\text { d'eau - masse eau }\end{array}$ & Commentaire \\
\hline AG314 & $\begin{array}{l}\text { Référentiel } \\
\text { Masse d'eau } \\
\text { souterraine - } \\
\text { Etat des lieux } \\
2019\end{array}$ & $\begin{array}{l}\text { Sables du } \\
\text { Landénien des } \\
\text { Flandres }\end{array}$ & $13 / 01 / 2021$ & Association Incertaine & $\begin{array}{l}\text { D'après information } \\
\text { de l'AEAP, selon } \\
\text { l'ancienne version de } \\
\text { la ME }\end{array}$ \\
\hline
\end{tabular}

L'historique des associations des versions antérieures du référentiel est disponible dans le dossier descriptif de l'export du point d'eau (format csv)

\section{- Paramètres hydrodynamiques}

\begin{tabular}{|c|c|c|c|c|c|c|c|c|}
\hline $\begin{array}{l}\text { Date } \\
\text { de } \\
\text { l'essai }\end{array}$ & $\begin{array}{l}\text { Type } \\
\text { de } \\
\text { l'essai }\end{array}$ & $\begin{array}{l}\text { Coefficient } \\
\text { d'emmagasinement }\end{array}$ & $\begin{array}{l}\text { Transmissivité } \\
\left(\mathrm{m}^{2} / \mathrm{s}\right)\end{array}$ & $\begin{array}{l}\text { Perméabilité } \\
(\mathrm{m} / \mathrm{s})\end{array}$ & $\begin{array}{l}\text { Débit } \\
\text { critique } \\
\left(m^{3} / h\right)\end{array}$ & $\begin{array}{l}\text { Débit } \\
\text { spécifique } \\
\left(\mathrm{m}^{2} / \mathrm{h}\right)\end{array}$ & $\begin{array}{l}\text { Débit max } \\
\text { exploitation } \\
\left(\mathrm{m}^{3} / \mathrm{h}\right)\end{array}$ & Références \\
\hline
\end{tabular}

Fig. 3. ADES table with missing hydrogeologic parameters

ADES database can provide to users total coliforms count for the quality information about a specific borehole, as for the groundwater near the Metz-en-Couture town. ADES can provide graphical results for Metz showing the trend of coliforms versus time during the sampled period (fig. 4). The several nested links to the repositories of data can be useful to downloaded zip files that might contain coliforms data for many specific wells or springs of a region. 
1448-Coliformes thermotolérants (UFC/100mL)

\begin{tabular}{|c|c|c|}
\hline $\begin{array}{l}\text { Min } \\
\text { mesuré }\end{array}$ & 00.0 & UFC/100mL \\
\hline $\begin{array}{l}\text { Max } \\
\text { mesuré }\end{array}$ & 00.0 & UFC/100mL \\
\hline
\end{tabular}

1448-Coliformes thermotolérants $(n /(100 \mathrm{~mL}))$

\begin{tabular}{|c|c|c|}
\hline Min mesuré & 00.0 & $\mathrm{n} /(100 \mathrm{~mL})$ \\
\hline $\begin{array}{l}\text { Max } \\
\text { mesuré }\end{array}$ & 00.0 & $\mathrm{n} /(100 \mathrm{~mL})$ \\
\hline
\end{tabular}

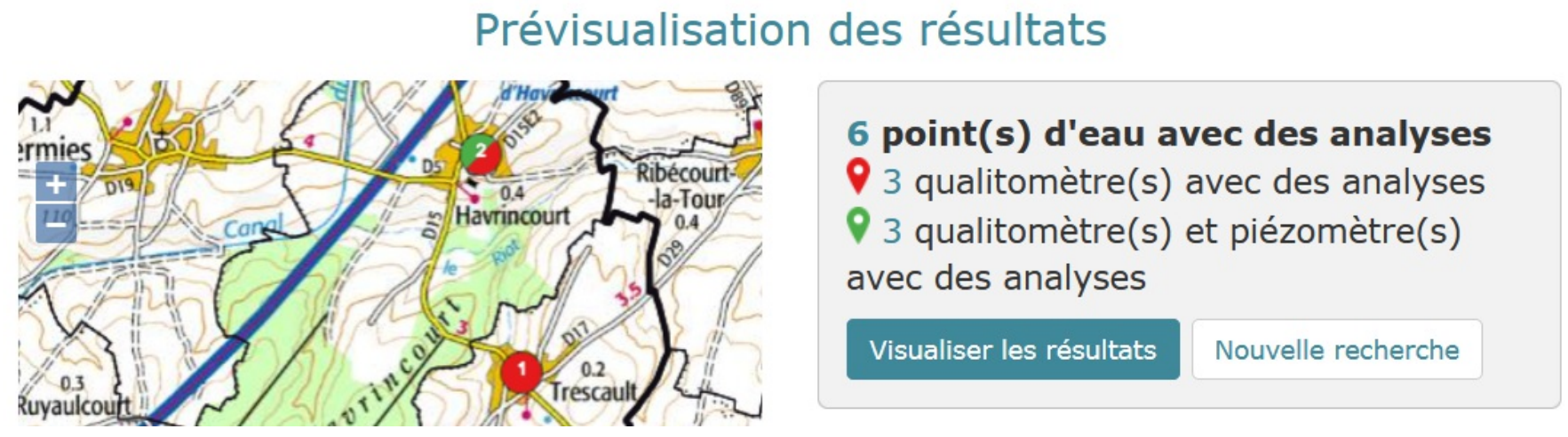

renseignée
ction du point d'eau
renseignée
ge de l'eau
renseignée
sin
is-Picardie
artement
De-Calais (62)
umune actuelle
cault (62830)
1-dit
Du Chateau D'Eau, Route De
zeaucourt
rdonnées $\mathbf{X}, \mathbf{Y}$
- des raisons de sécurité, ces
mations ne sont pas rendues
iques.
ude
m
te géologique au $\mathbf{1 / 5 0} 000$
ibrai (nº036)
seignement complémentaires
- Fiche InfoTerre
Dernière mise à jour
$28 / 01 / 2020$

\begin{tabular}{|c|c|c|c|c|c|}
\hline $24 / 04 / 1974$ & 曲 & $\curvearrowright$ & $28 / 05 / 2019$ & 曲 & ค \\
\hline Uniquement les donr & cor & ctes & & $\nabla$ & $?$ \\
\hline
\end{tabular}

BSS000DKQX (00367X0019/P1) - - Pas-De-Calais (62)

du 24/04/1974 au 28/05/2019 - Uniquement les données validées correctes

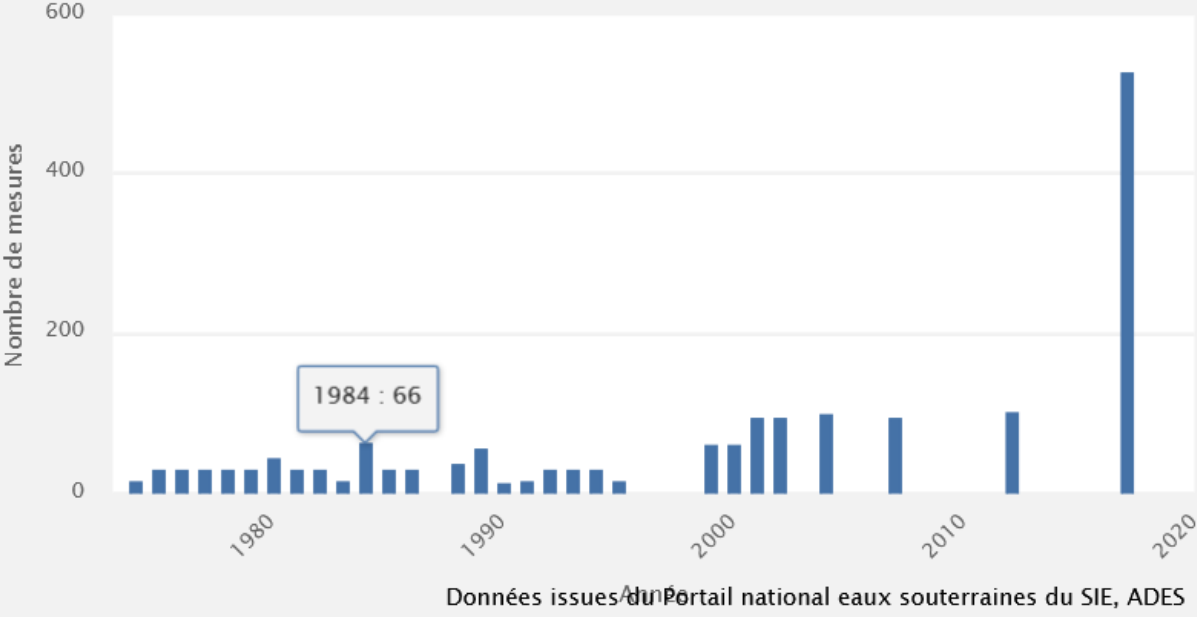

Par Année Par Mois

Fig. 4. ADES total coliforms data from groundwater samples near Metz town

Unfortunately, the request for further microbial parameters, such as Escherichia coli, at many localities was 
always rejected from ADES (i.e., "The requested URL was rejected") probably because there are no data. Finally, the link for the Hub'eau platform services (www.hubeau.eaufrance.fr) provided by the authors in Section 4.3 does not work.

In conclusion, the ADES database is a suitable tool for groundwater management studies in France. However, in the paper, a detailed discussion about the limitations of the ADES repository is required. Today, the main ADES aim mentioned in the Conclusions and Perspective section of the paper, i.e. "researchers from all over the world can work on problems related to groundwater quality" in France using data from the ADES database, seems to be ambitious. In this work, the authors have overestimated actual ADES potentiality. ADES requires an accurate restyling and uploading of many basic data which may characterize maps of groundwater piezometric surfaces, pumping well (or spring) flowrates and corresponding drawdowns, and hydrologic parameters of the France groundwaters.Tables of downloaded files should be reorganized to allow the users an easier visualization removing text descriptions and providing measurements with international standard units. ADES data for groundwater quality and quantity is sparse and has to be integrated to be used in groundwater modeling for water resource management. Moreover, the authors should include in the paper a user-friendly description of a few practical examples of ADES consultations, which may assist users around the world in data selection and download of the required data. 